\title{
Az oktatás céljáról, a tanári szerepről, a diákszerepről és osztálytermi interakcióról vallott pedagógusi nézetek
}

\author{
Kardos Melinda \\ Babeș-Bolyai Tudományegyetem Szatmárnémeti Kihelyezett Tagozat
}

\begin{abstract}
Az osztálytermi interakciók és a tanári nézetek fontos helyet foglalnak el a hatékony oktatási folyamat megvalósulásában. Jelen tanulmány elsö részében leirja azon kutatások eredményeit, melyek a nézetekre és osztálytermi interakcióra fókuszálnak. Második részében jelen tanulmány a kapcsolatot próbálja feltárni a pedagógiai nézetek és osztálytermi interakciók, valamint osztálytermi gyakorlat között. A tanulmány eredményei ellentmondásokat találtak a tanári nézetek és az osztálytermi gyakorlat között, melyek a továbbiakban kerülnek részletes bemutatásra.
\end{abstract}

Kulcsszavak: oktatási folyamat, tanári nézetek, osztálytermi interakció, tanári szerep, tanulói szerep

$\mathrm{Az}$ iskolai tanulás hatékony megvalósulásának alapfeltétele a folyamatban részt vevő szereplők: a tanár és a tanuló közötti interakciók eredményes alakulása.

A tanulói és pedagógusi szerepváltozások közül a pedagógusmagatartás és pedagógusszerep alakulási folyamatát tekintve a reformpedagógia megjelenésével jól látható az ismeretközlő, távolságtartó, értékelés centrikus magatartás háttérbe szorulása. Egyre inkább az együttmüködőbb interakciót érvényesítő, segítő, motiválásra orientált, differenciált bánásmódra képes pedagógiai magatartás a megerősített, ezen túlmenően az alkalmazkodó bánásmódot érvényesítő, a gyerekeket munkatársként kezelő magatartás kívánatos a pedagógus munkájában (Bábosik, 2006).

$\mathrm{Az}$ adaptatív bánásmódnak a pedagógusi munkában nem csak érvényesülnie kellene, hanem adaptatív magatartást kellene kifejleszteni a tanulókban is, mivel a mindennapi életben bekövetkező gyors ütemű változás és fejlődés, megújulásra képes szakemberek foglalkoztatását és képzését teszi szükségessé. A megújulást elősegítő szemlélet viszont nehézkesen épül be a mindennapi oktatási gyakorlatba.

A tanulási folyamatot megúiító szemlélet implementálásának nehézségeiről ír Halász (2014) tanulmányában, melyben a tanulás centrikus oktatáspolitikákkal és ezek sikerességének feltételeivel foglalkozik. Kiemeli azt, hogy a tanulási folyamat fejlesztése, bár jelentős imple- mentációs kihívást jelent, a kihívások ellenére több fejlett országban is egyik legfontosabb célja lett az oktatáspolitikáknak, ami a globális gazdasági versenyben való előnyszerzés miatt lett indokolt. A fejlett országok meglátása szerint, a globális versenypozíció javításának legfontosabb tartalékát az emberi erőforrás fejlesztése jelenti. Például a kelet- és délkelet európai országokban olyan curriculumreformokat vezettek be, melyek a kognitív képességek tömeges fejlesztését célozták, ugyanakkor ezek a reformok az osztálytermi tanulásszervezési folyamatok változását is maguk után vonták (Halász, 2014).

A tanulás eredményességének javítása, a tárgyaltak értelmében, elsődleges fontossággal bír. Bizonyítja ezt az is többek között, hogy ma már egy új tudományág foglalkozik a tanulási folyamat hatékonyságát befolyásoló tényezők vizsgálatával.

A "tanulástudomány” (learning science) azoknak a kognitív és társas folyamatoknak a megértését és megismerését tűzi ki célul, melyek elősegítik az eredményesebb tanulást, olyan tudás elsajátítását, amely az osztályteremben és más környezetben egyaránt hasznosítható.

Jelen kutatás a tanulástudomány körébe tartozó kutatások körét bővíti.

Kiindulópontként fontos megemlítenünk a tanulás általunk is alkalmazott konstruktivista értelmezési keretrendszerét, melyet kutatásunk felépítése során is szem előtt tartunk. 
Az oktatás céljáról, a tanári szerepről, a diákszerepről...

A tanulásról való mai gondolkodást a „konstruktivizmus" modellje írja le, amely szerint a tanulás a tudás személyes belső „felépítése”. Az emberi tudásról alkotott ezen nézetet elfogadják a tanuláskutatással foglalkozó szakmai közösségen belül, arról viszont élesen vitáznak, hogy ennek következtében az iskolai gyakorlat tényleges változása meg kell-e történjen.

Néhány szerző például az alábbi cimmel jelentetett meg tanulmányt az amerikai pszichológiai társaság folyóiratában: „Miért nem működik a minimálisan irányított tanítás: a konstruktivista, felfedezéses, probléma-alapú, tapasztalati és kutatás-alapú tanítás kudarcának elemzése". A vita elemzése (lásd Kirschner et al., 2006; Scmidt el al., 2007; Hmelo-Silver et al. 2007; Kirschner et al., 2007) azt is mutatja, hogy a kutatók körében a legnagyobb kérdés valószínúleg az, hogy a tudományos kutatás világából át lehet-e lépni a mindennapi oktatás világába. Mivel a két világot teljesen más logika jellemzi, ha a tudományos kutatás normái szerint igazuk is lehetne az elméletalkotóknak a hatékony tanulás értelmezését tekintve, ennek az igazságnak eszerint az értelmezés szerint kevés a jelentősége a pedagógiai gyakorlat javítását célzó cselekvés számára.

Halász (2014) leírása szerint Eric de Corte ${ }^{1}$, aki többek között az Európai tanuláskutatási társaság EARLI² alapító tagja volt, 2010-ben közölt tanulmányában a tanulásról való mai tudás legfontosabb elemeit négy pontban foglalta össze: „Constructive”, azaz a tudás belső személyes felépítésének elemére utal.

- „Self-regulated” - az önszabályozó mechanizmusok müködésének elemére utal.

- "Situative” - a kontextushoz kötődés elemére utal.

- "Collaborative” - a tanulás társas vagy szociális természetére utal.

Ezeket írja le a mozaikszóba foglalt „CSSC learning " tömörítés, amely az eredményes ta-

1 Tanulmány adatai: de Corte, E. (2010): Historical developments in the understanding of learning. In: Dumont H., Istance, D. \& Benavides, F. (eds.) The Nature of Learning: Using Research to Inspire Practice. OECD. Paris, 36-67.

2 Teljes nevén European Association for Research on Learning and Instruction, azaz a „Tanulás és Tanítás Kutatóinak Európai Szövetsége". nulás fent bemutatott négy meghatározó elemét mutatja be. Bár ezek az elemek régebb óta ismertek, a legtöbb országban nem jelennek meg a mindennapi iskolai gyakorlatban. A tanuláskutatások gyakorlati hasznosítása céljából az alábbi módon próbálták a gyakorlat nyelvére fordítani a tanuláskutatás eredményeit: „a tanár-centrikus megközelítés felől a tanuló-centrikus megközelítés felé kell elmozdulni” vagy „kooperatív tanulásszervezési formákat kell alkalmazni" (Halász, 2014)-

Az EARLI szakmai szervezethez hasonló szakmai szervezetekbe tömörülő tanulás és tanítás kutatásával foglalkozó szakemberek, a tanulásról való tudás gyakorlati alkalmazásának nehézségeit általában abban látják, hogy leginkább a tudástranszfer szemlélet jelenik meg az oktatási gyakorlatban, illetve kommunikációs problémák gátolják a tanulási folyamatok átalakítását (Halász, 2014)

$\mathrm{Az}$ iskolai gyakorlat a legtöbb helyen ma is a korábban kialakult hiedelmek és rutinok alapján valósul meg. Legjobban ezt a nézetet a pedagógus kommunikációban ma is gyakran használt „tudásátadás" metafora fejezi ki. A legtöbb országban az iskolai gyakorlat azt a nézetet követi, miszerint a tudás átadható, mivel olyan implicit tanuláselméletet követ, amely „ismeretként” vagy „műveltségként" kezeli a tudást. A "tanulás tanítása” vagyis a tanulás bonyolult képességének fejlesztése nem igen jelenik meg szakmai feladatként.

Halász (2014) kiemeli, hogy bár vannak olyan kezdeményezések is, amelyek a tanulásról való mai tudáshoz próbálják alakítani az iskolai gyakorlatot, ezek azonban általában szűk körben maradnak és az „alternatív” jelzővel utalnak gyakran ezekre a kezdeményezésekre (Halász, 2014).

Alternatív iskoláknak a II. világháború után kialakult iskolákat nevezik a neveléstudományi szakirodalomban. A Pedagógiai Kislexikonban megjelenő meghatározások szerint, az alternatív jelzőt tágabb értelmezésben is használhatjuk mindazon iskolákra, melyek eltérnek a hagyományos iskoláktól (Langerné-Buchwald, 2010).

Párhuzamot vonva a két oktatási paradigma irányelvei között a hagyományos és alternatív oktatás sajátosságait az 1. táblázatban összesítette Cucosra ${ }^{3}$ támaszkodva Trif (2012).

\footnotetext{
${ }^{3}$ Constantin Cucos: Pedagogia generală,
} 


\begin{tabular}{|c|c|}
\hline A hagyományos paradigma irányelvei & Az alternatív paradigma irányelvei \\
\hline $\begin{array}{l}\text { A tartalomra helyezi a hangsúlyt, az információk } \\
\text { helyes, pontos és végleges elsajátítására. }\end{array}$ & $\begin{array}{l}\text { A hangsúly az információk közötti kapcsolatokon } \\
\text { van, az új koncepciók felfogásán, kihangsúlyozva a } \\
\text { folyamatos tanulás szükségességét. }\end{array}$ \\
\hline A tanulás egy eredmény. & A tanulás egy folyamat. \\
\hline $\begin{array}{l}\text { Létezik egy hierarchikus és egy alárendelő struktúra, } \\
\text { ahol a konformizmus (az átlagnak megfelelő } \\
\text { viselkedés) a megerősített, az átlagtól eltérő } \\
\text { gondolkodásmóddal szemben, mely nem megerősített, } \\
\text { háttérbe szorított. }\end{array}$ & $\begin{array}{l}\text { Jelen vannak a nem hierarchikus irányelvek, a tanárok } \\
\text { és a tanulók leginkább úgy tekintenek egymásra, mint } \\
\text { emberekre és nem, mint szerepekre. }\end{array}$ \\
\hline $\begin{array}{l}\text { A tanulás struktúrája szorosan meghatározott, kötelező } \\
\text { oktatási programok jellemzik. }\end{array}$ & $\begin{array}{l}\text { A tanulás struktúrája flexibilis, instruktív-formatív } \\
\text { folyamatok mennek végbe, választható tantárgyak } \\
\text { vannak és alternatív munkamódszerek. }\end{array}$ \\
\hline $\begin{array}{l}\text { Az ismereteket egy mindenki számára azonos, kötelező } \\
\text { ritmusban sajátítják el. }\end{array}$ & $\begin{array}{l}\text { Elfogadja azt a tényt, hogy a fejlődési potenciálok } \\
\text { nézőpontjából a tanulók különböznek, ez a tény } \\
\text { indokolja a tananyag elsajátításának eltérő ritmusát. }\end{array}$ \\
\hline A hangsúly az elért sikerek számára tevődik. & $\begin{array}{l}\text { A hangsúly annak az egyénnek a } \\
\text { személyiségfejlődésére tevődik, aki tanul. }\end{array}$ \\
\hline $\begin{array}{l}\text { Túlnyomó részt a külső környezetnek tulajdonít } \\
\text { jelentős szerepet. }\end{array}$ & $\begin{array}{l}\text { Előnyben részesíti a képzelőerő és kreativitás } \\
\text { aktiválását, a tanuló belső tapasztalatainak potenciálját. }\end{array}$ \\
\hline $\begin{array}{l}\text { A lineáris, analitikus gondolkodás fejlődésére tevődik a } \\
\text { hangsúly, a bal agyfélteke potenciáljára. }\end{array}$ & $\begin{array}{l}\text { Arra törekszik, hogy mindkét agyféltekét igénybevevő } \\
\text { oktatási folyamatot müködtessen, követve a bal } \\
\text { agyfélteke racionalitásának összekapcsolását a jobb } \\
\text { agyfélteke intuícióival. }\end{array}$ \\
\hline $\begin{array}{l}\text { A tanulók értékelése szigorúan meghatározott címkék } \\
\text { alapján történik, ez a tény olykor stigmatizáláshoz } \\
\text { vezethet, a tanuló korlátozásához az adott címkéhez } \\
\text { mérten. }\end{array}$ & $\begin{array}{l}\text { A címkézésnek másodlagos/kisegítő szerepe van, nem } \\
\text { szükséges, hogy ez meghatározott értékelés legyen, } \\
\text { mely leírja és stigmatizálja a tanulót. }\end{array}$ \\
\hline $\begin{array}{l}\text { A tanulók teljesítményét a külső normákhoz és } \\
\text { standardokhoz viszonyítják. }\end{array}$ & $\begin{array}{l}\text { A tanulókról írt jelentésben teljesítményüket } \\
\text { önmagukhoz mérik, lehetőségeik és az elért szint } \\
\text { függvényében. }\end{array}$ \\
\hline $\begin{array}{l}\text { A hangsúly az elméleti jellegű ismeretekre van } \\
\text { helyezve. }\end{array}$ & $\begin{array}{l}\text { Az elméleti ismeretek bővítésére és ezek gyakorlati } \\
\text { tapasztalatokkal történő megerősítésére helyezik a } \\
\text { hangsúlyt az osztálytermen belül és az osztálytermen } \\
\text { kívül is. }\end{array}$ \\
\hline $\begin{array}{l}\text { Bürokrácia és kitartás a közösség javaslataival } \\
\text { szemben. }\end{array}$ & $\begin{array}{l}\text { A közösség javaslatai beszámítottak-számba vettek és } \\
\text { támogatottak. }\end{array}$ \\
\hline $\begin{array}{l}\text { Az osztálytermek szigorúan funkcionális szempontok } \\
\text { szerint szervezettek és tervezettek. }\end{array}$ & $\begin{array}{l}\text { Az osztálytermek szervezése és tervezése szem } \\
\text { előtt tartja az ergonómiai szempontokat (világítás, } \\
\text { szellőztetés, fizikai kényelem). }\end{array}$ \\
\hline $\begin{array}{l}\text { A tanulást a folyamat közben valósítják meg, az } \\
\text { információáramlás a tudományos fejlődéshez mérten } \\
\text { történik. }\end{array}$ & $\begin{array}{l}\text { A tanulásnak előremutató jellege van, ami a jövőben } \\
\text { fog kiteljesedni, az információ áramlás a tudományos } \\
\text { fejlődést előrevetítik. }\end{array}$ \\
\hline $\begin{array}{l}\text { Az információ iránya egy irányúnak értelmezett, a } \\
\text { tanártól a diák felé. }\end{array}$ & $\begin{array}{l}\text { Az együttes tanulás a megerősített a tanár-diák } \\
\text { kapcsolatban. }\end{array}$ \\
\hline
\end{tabular}

1. táblázat: Az oktatási paradigma irányelvei (Cucos, 1996) idézi Trif, 2012. 20-21. o.). 
Az oktatás céljáról, a tanári szerepről, a diákszerepről...

Összegezve a táblázatban megjelenített sajátosságokat, láthatjuk, hogy a hagyományos oktatási paradigma az információátadásra helyezi a hangsúlyt, a tanár-diák kapcsolatot hierarchikus módon alakul és az értékelés külső normákhoz és standardokhoz viszonyított, ellenben az alternatív paradigma szemlélete szerint a hangsúly az új információk közötti kapcsolatra tevődik, a tanár-diák kapcsolat nem hierarchikus irányelvekre épül, a tanulók teljesítményét pedig leginkább önmagukhoz méri.

Jelen tanulmányban arra keressük a választ, hogy melyik nézet szerint (hagyományos vagy alternativ) vélekednek a megkérdezett pedagógusok az oktatás céljáról, tanárszerepről, tanulószerepről és mindezen nézetek hogyan tükröződnek az osztálytermi folyamatok vezetéséről vallott nézeteikben.

Az osztály vezetésére számos stratégia ismeretes a szakirodalomban és ezek a stratégiák széles körben elérhetőek a tanárok számára.

Ritter és Hancock (2007) tanulmányukban Glickman, Tamashiro (1980) és Wolfgang $(1995)^{4}$ modelljét mutatják be, melyben az osztályvezetési stratégiákat három típusba sorolják:

a) az intervencionalista (beavatkozó) stratégia szerint a tanulók úgy tanulják meg a megfelelö viselkedést, ha az adott viselkedés megerősített a tanár által, vagyis jutalmak illetve büntetések által. $\mathrm{Az}$ intervencionalista tanár állításai szerint a tanároknak ajánlott a magas fokú kontroll lépéseit gyakorolni a tanulók felett az osztálytermi tevékenységekben.

b) a nem-intervencionalista (a be nem avatkozó) a másik végletet képviseli, mely szerint a tanulók egy belső hajtóerővel, késztetéssel (drive) rendelkeznek, melynek feladata, hogy kifejeződjék a világban. Következésképpen a nem-intervencionalisták kiemelik, hogy a tanulókat engedni kell szabadon megnyilvánulni és hatást gyakorolni az osztálytermi kontextusban, illetve a tanároknak kevésbé kellene beavatkozniuk a tanulók viselkedésének irányításába.

c) a két véglet között az interakcionalisták szerint a tanuló a külső környezeti ingerekkel, tárgyakkal és emberekkel kapcsolatba kerülve sajátítja el a megfelelő viselkedést. Szerintük a tanulóknak és tanároknak közösen kellene felelősséget vállalniuk az osztálytermi folyamatok alakulásában (Martin, Yin és Baldwin, 1998 idézi Ritter és Hancock, 2007).

Hasonló módon vizsgálta az osztálytermi gyakorlat és a nézetek kapcsolatát Rahimi és Asadollahi (2012). Tanulmányukban megvizsgálták a kapcsolatot az iráni tanárok osztályvezetési irányultsága és a tanítási stílus között. A vizsgálat során háromszáz tanár töltötte ki az ABCCTAP (Attitudes and Beliefs on Classroom Control inventory and Teaching Activities Preference questionnaire) kérdőívet. A begyüjtött adatok értelmezése során arra a következtetésre jutottak, hogy a legtöbb iráni tanár óravezetési stílusát tekintve a beavatkozás híve (intervencionalista). Továbbá az eredmények szerint azok a tanárok, akik intervencionalistábbak voltak, az óravezetéskor sokkal több „tanítás” jellegü gyakorlatot használtak, mint azok a társaik, akik az óravezetési irányultságukat tekintve interakcionalistának bizonyultak. Egy mélységi elemzés feltárta, hogy az óravezetésre irányuló nézetek 28\%-ban előre jelezhetik a gyakorlatban megjelenő tanítási stílust (Rahimi és Asadollahi, 2012).

A továbbiakban metaanalízis formájában összesítjük azokat a kutatásokat, melyek a pedagógusi nézetek, osztálytermi interakciók összefüggéseit vizsgálják (1. 2. táblázat).

\footnotetext{
4. Tanulmány adatai: Glickman, C. E Tamashiro, R. (1980): Clarifying teachers' beliefs about discipline. Educational Leadership, 37. 6. sz., 459-464.
} 
Kardos Melinda

\begin{tabular}{|c|c|c|c|}
\hline $\begin{array}{l}\text { Szerzők, } \\
\text { évszám }\end{array}$ & Kutatás célja & Vizsgálati eljárás & Eredmények \\
\hline $\begin{array}{l}\text { Knoblauch, D., } \\
\text { Chase, M., A. } \\
\text { (2015). }\end{array}$ & $\begin{array}{l}\text { Ebben a tanulmányban } \\
\text { a kutatók } \\
\text { pedagógus hallgatók } \\
\text { én-hatékonyságára } \\
\text { vonatkozó nézeteit } \\
\text { vizsgálták arra } \\
\text { vonatkozóan, hogy az } \\
\text { iskolák elhelyezkedése } \\
\text { (vidéki, külvárosi, } \\
\text { városi) befolyásolja-e } \\
\text { a tanár hatékonyság } \\
\text { érzetét. }\end{array}$ & $\begin{array}{l}\text { Összesen } 368 \text { hallgató } \\
\text { vett részt a kutatásban. } \\
\text { Eszközként a } \\
\text { TSES skála- (Teacher } \\
\text { Sense of Efficacy Scale) } \\
\text { Tschannen-Moran és } \\
\text { Woolfolk Hoy (2001) } \\
\text { által kidolgozott rövid } \\
\text { változatát alkalmazták. }\end{array}$ & $\begin{array}{l}\text { A pedagógiai gyakorlatot követően szignifikáns } \\
\text { növekedés volt kimutatható a pedagógushallgatók } \\
\text { én-hatékonyság érzetében. Azonban a városi } \\
\text { környezetben tanító hallgatók szignifikánsan } \\
\text { alacsonyabb én-hatékonyság érzetet mutattak, } \\
\text { mint a külvárosi-, illetve falusi környezetben } \\
\text { tanítók. Emellett a kutatásban kitértek a pedagó- } \\
\text { gushallgatók attribúcióinak vizsgálatára a tanítást } \\
\text { követően. Mindhárom környezetben a pedagógus } \\
\text { hallgatók ugyanolyan mértékben alkalmaztak } \\
\text { külső ok-tulajdonítást, megtalálhatóak voltak } \\
\text { mindannyik esetében az én-kiszolgáló attribúciós } \\
\text { torzítások illetve az alapvető attribúciós hiba. }\end{array}$ \\
\hline $\begin{array}{l}\text { Pakarinen, } \\
\text { E., Aunola, } \\
\text { K., Kiuru, N., } \\
\text { Lerkkanen, M. } \\
\text { K., Poikkeus, A. } \\
\text { M., Siekkinen M., } \\
\text { Numi,J. E. (2014). }\end{array}$ & $\begin{array}{l}\text { A kutatásban } \\
\text { az osztálytermi } \\
\text { interakciók } \\
\text { minőségének és a } \\
\text { tanulók viselkedésének } \\
\text { kapcsolatát vizsgálták } \\
\text { a kutatók teljesítmény } \\
\text { helyzetekben. } \\
\end{array}$ & $\begin{array}{l}70 \text { osztályból származó } \\
166 \text { finn gyermek (első- } \\
\text { és második osztályosok) } \\
\text { teljesítménnyel } \\
\text { kapcsolatos viselkedését } \\
\text { tanulmányozták } \\
\text { kihívást jelentő teszt } \\
\text { helyzetekben. }\end{array}$ & $\begin{array}{l}\text { Az eredmények kihangsúlyozták a gyerekek } \\
\text { adaptív teljesítmény viselkedésének elérése } \\
\text { érdekében, a meleg és támogató osztálytermi } \\
\text { interakciók fontosságát. Ugyanakkor azt is } \\
\text { kiemelték a kutatás eredményei, hogy a tanárok } \\
\text { a gyerekek feladathoz való hozzáállásához } \\
\text { igazítják az osztálytermi interakciókat. }\end{array}$ \\
\hline $\begin{array}{l}\text { Riensties, B., } \\
\text { Brower, N., } \\
\text { Lygo-Baker, S. } \\
\text { (2013). }\end{array}$ & $\begin{array}{l}\text { A kutatásban } \\
\text { a TPACK } \\
\text { (Technological } \\
\text { Pedagogical Content } \\
\text { Knowledge) program } \\
\text { hatását vizsgálták. }\end{array}$ & $\begin{array}{l}\text { Kilenc felsőoktatási } \\
\text { intézményből, összesen } \\
73 \text { pedagógus vett részt } \\
\text { egy online tanárképző } \\
\text { programban. Az adatokat } \\
\text { a TPACK segítségével } \\
\text { gyűjtötték, illetve az elő- } \\
\text { és utóméréshez a Tanári } \\
\text { Hiedelmek és Szándékok } \\
\text { (Teacher Beliefs and } \\
\text { Intentions) kérdőívet } \\
\text { használták a kutatók. }\end{array}$ & $\begin{array}{l}\text { A kutatási eredmények azt mutatták, hogy a vizs- } \\
\text { gált pedagógusoknak szignifikánsan eltérő nézetei } \\
\text { és szándékai voltak. Az eredmények arra utaltak, } \\
\text { hogy a tanítással kapcsolatos ideális koncepciók } \\
\text { nagyban eltértek attól, amit gyakorlatba ültettek a } \\
\text { vizsgált pedagógusok. } \\
\text { A } 33 \text { résztvevő eredményei, akik a pre- és poszt- } \\
\text { tesztben is részt vettek, azt mutatják, hogy a } \\
\text { TPACK program hatására fejlődés volt kimutat- } \\
\text { ható a vizsgált pedagógusok körében. Az prog- } \\
\text { ramban az idő előrehaladtával a pedagógusok egyre } \\
\text { kevésbé voltak meggyőződve a tudásátadás érde- } \\
\text { méről, vagyis változás következett be nézeteikben. }\end{array}$ \\
\hline Petek, E. (2013) & $\begin{array}{l}\text { A tanulmányban } \\
\text { a kutató szeretné } \\
\text { feltárni a kapcsolatot } \\
\text { a tanárok nézetei } \\
\text { (az osztálytermi } \\
\text { interakcióról) és } \\
\text { az osztálytermi } \\
\text { gyakorlataik között. } \\
\end{array}$ & $\begin{array}{l}\text { Alkalmazott módszerek: } \\
\text { félig stuktúrált interjú } \\
\text { és támogatott felidézés } \\
\text { technika egy nem angol } \\
\text { anyanyelvű és egy } \\
\text { anyanyelvű angol tanár } \\
\text { esetében. }\end{array}$ & $\begin{array}{l}\text { Az eredmények azt mutatják, hogy a tanári } \\
\text { nézetek és a gyakorlatok, nem minden esetben } \\
\text { függenek össze. A tanulmány rávilágít a tanárok } \\
\text { nézetei és az osztálytermi interakciók közötti } \\
\text { különbségekre és kiemeli a további kutatások } \\
\text { és tréningek szükségességét, amelyek a tanárok } \\
\text { tudatossági szintjét növelik az osztálytermi } \\
\text { interakcióval kapcsolatosan. }\end{array}$ \\
\hline $\begin{array}{l}\text { Rahimi, M., } \\
\text { Asadollahi, F. } \\
\text { (2012) }\end{array}$ & $\begin{array}{l}\text { A tanulmány iráni } \\
\text { tanárok osztály } \\
\text { vezetési stílusát } \\
\text { vizsgálja, valamint } \\
\text { azokat a tanítási } \\
\text { módszereket, } \\
\text { amelyeket a tanárok } \\
\text { az angol nyelvórákon } \\
\text { alkalmaznak. }\end{array}$ & $\begin{array}{l}300 \text { tanár töltötte ki az } \\
\text { „Attitűdök és hiedelmek } \\
\text { az osztály irányításról } \\
\text { „skálát, valamint „A } \\
\text { tanítási módszerek és } \\
\text { hatékonyság „ kérdoívet. }\end{array}$ & $\begin{array}{l}\text { Az eredmények szerint a legtöbb iráni tanár } \\
\text { óravezetési stílusát tekintve a beavatkozás híve } \\
\text { (intervencionista). Továbbá az eredmények szerint } \\
\text { azok a tanárok, akik sokkal intervencionistábbak } \\
\text { voltak az osztálytermi interakciókban sokkal } \\
\text { több tanítási gyakorlatot használtak, mint azok a } \\
\text { társaik, akik az óravezetési irányultságot tekintve } \\
\text { interakcionalistának bizonyultak. Egy alaposabb } \\
\text { elemzés feltárta, hogy az óravezetési irányultság } \\
\text { 28\%-ban előrejelezheti a tanítási stílust. }\end{array}$ \\
\hline
\end{tabular}


Az oktatás céljáról, a tanári szerepről, a diákszerepről...

\begin{tabular}{|c|c|c|c|}
\hline $\begin{array}{l}\text { Eveyik, A. E., } \\
\text { Kurt, G., Mede, } \\
\text { E. (2009) }\end{array}$ & $\begin{array}{l}\text { A tanulmány egy } \\
\text { török angol nyelv, } \\
\text { mint idegen nyelv, } \\
\text { tanár nézeteit vizsgálja } \\
\text { az osztály vezetésével, } \\
\text { irányításával } \\
\text { kapcsolatosan, } \\
\text { valamint vizsgálta } \\
\text { az osztály vezetéssel } \\
\text { kapcsolatos nézeteket } \\
\text { és a valós gyakorlat } \\
\text { között megjelenő } \\
\text { hasonlatokat és } \\
\text { eltéréseket. }\end{array}$ & $\begin{array}{l}\text { Vizsgálati eljárásként az } \\
\text { attitűd és nézetek vizsgá- } \\
\text { latára az osztály vezetési } \\
\text { leltár (ABCC- Attitudes } \\
\text { and Beliefs on Classroom } \\
\text { Control) került alkalma- } \\
\text { zásra, a tanítási filozófia } \\
\text { vizsgálata pedig egy } \\
\text { támogatott felidézést } \\
\text { alkalmazó ülés keretében } \\
\text { zajlott. A kutatásban egy } \\
29 \text { éves tanár vett részt, } \\
\text { aki } 7 \text { év oktatási tapasz- } \\
\text { talattal rendelkezett. }\end{array}$ & $\begin{array}{l}\text { A kutatás eredményeinek elemzése során } \\
\text { együttjárást mutattak ki a résztvevő tanár nézetei } \\
\text { és valós osztály vezetési gyakorlatai között. }\end{array}$ \\
\hline $\begin{array}{l}\text { Ritter, J.,T., } \\
\text { Hancock, D., R., } \\
(2007)\end{array}$ & $\begin{array}{l}\text { Ebben a tanulmányban } \\
\text { a tanári végzettség } \\
\text { forrása (hagyomá- } \\
\text { nyos vagy alternatív), } \\
\text { a tanár tapasztalati } \\
\text { szintje (tapasztalt } \\
\text { vagy kezdő) és a tanár } \\
\text { osztály vezetési stílusa } \\
\text { (intervencionista, } \\
\text { nem intervencionista } \\
\text { vagy interakcionalista) } \\
\text { közötti összefüggé- } \\
\text { seket vizsgálták. }\end{array}$ & $\begin{array}{l}\text { Az attitűd és nézet skálát } \\
\text { alkalmazták a kutatás } \\
\text { során. (ABCC Attitudes } \\
\text { and Beliefs on Classroom } \\
\text { Control) } 158 \text { középiskolai } \\
\text { tanár vett részt a } \\
\text { felmérésben. }\end{array}$ & $\begin{array}{l}\text { Arra a következtetésre jutottak, hogy sem a } \\
\text { tanárok képesítésének forrása sem a tapasztalati } \\
\text { szint önmagában nem befolyásolja, nincs } \\
\text { hatással a tanárok osztályvezetési stílusára. } \\
\text { Ugyanakkor, azok a tanárok, akik hagyományos } \\
\text { képesítéssel és sok év tapasztalattal rendelkeztek } \\
\text { szignifikánsan kevesebb kontrollt gyakoroltak } \\
\text { az osztály tevékenységekre és a tanulói } \\
\text { viselkedésekre, azon kollégáikkal szemben, } \\
\text { akik más képesítési és tapasztalati háttérrel } \\
\text { rendelkeztek. }\end{array}$ \\
\hline
\end{tabular}

2. táblázat: A kutatás témájával kapcsolatos kutatások összegzése időrendi sorrendben

A szakirodalom részleges áttekintését követően, illetve a gyakorlati megfigyeléseinkre alapozva a központi kérdés, amire a kutatás során választ keresünk a következő: Milyen módon befolyásolja a tanári nézetrendszer az osztálytermi interakciókat?

Feltételezzük, hogy a tanárok nézetrendszere és az osztálytermi kommunikációs viselkedése között összefüggéseket figyelhetünk meg: a pedagógusok nézeteiben megjelenik az alternatív szemlélet, ellenben az osztálytermi folyamatok vezetésében leginkább a hagyományos szemléletet alátámasztó intervencionalista osztályvezetési stílus jelenik meg.

Kutatásunk hipotézisének vizsgálata érdekében megyei szinten, Szatmár megyében, Romániában végzünk kérdőíves felmérést a tanári nézetek és az osztálytermi interakciós megnyilvánulások feltárása érdekében.

Összefüggéseket vizsgálunk a tanárok nézetrendszere és az osztálytermi interakciók között: alternatívak vagy hagyományosak-e a vizsgálatba bevont tanárok nézetei és ezek összefüggenek-e az osztálytermi interak- ciók formájával - intervencionalista-nem intervencionalista-interakcionalista.

A kvalitatív mintavételi eljárások közül a minta-előstruktrálás-szelektív mintavételi aljását alkalmaztuk. Az eljárás jellemzői és lehetőségei Sántha (2009) leírása szerint: világosan megfogalmazott előfeltevések, információra van szükségünk a vizsgált változók eloszlásáról, az eseteket viszonylag nagy számuk miatt össze lehet hasonlítani. Az esetek összehasonlítását csak az előre meghatározott dimenziók mentén lehet elvégezni, így az új és váratlan összefüggések felfedezése csak korlátozott számban lehetséges. Kutatásunkban viszonylag világosan megfogalmazott előfeltevéseink voltak a tanári nézetek és az osztálytermi interakció összefüggéseit illetően. Előfeltevésünk szerint a hagyományos nézeteket jelennek meg inkább a pedagógusok nézeteiben és intervencionalista osztályvezetési stílus a leggyakoribb.

A vizsgált változók eloszlásának vizsgálata érdekében kérdőívet alkalmaztunk. A kérdőívet megyei szinten a magyartanárok segítségével jutattuk el a magyar nyelven oktató iskolákba. 
Kardos Melinda

Önkéntes formában, anonim módon kértük a kérdőív kitöltését, ami hatást gyakorolt a mintaszámra és a minta eloszlására. Ennek következtében kutatásunk mutató értékű és modellkutatásnak tekinthető, ez alatt azt értjük, hogy olyan modellt próbálunk ki egy kisebb mintán, ami nagyobb mértékű ráfordítással (több ember bevonása - hosszabb idő - nagyobb populáció) bármikor kiterjeszthető egy nagyobb mintára - bármilyen kontextusban, országhatártól függetlenül.

A kérdőív az alábbi részelemekre bontható:

- Demográfiai kérdések

- Nézetek feltárása: a trianguláció elvének szem előtt tartása érdekében a nézetek vizsgálatára három különböző módot választottunk:

1. A hagyományos és alternatív oktatási paradigmát leíró kijelentések értékelése egy 4 fokú Likert-típusú skálán: a tanulásra, a tanári szerepre, a tanulói szerepre, az osztálytermi interakcióra, az osztályvezetési stílusra vonatkozóan.

2. Metaforaválasztás.

3. Mondatbefejezés-technika.
A kérdőíves felmérésben összesen 383 pedagógustól kaptunk vissza önkéntesen, anonim módon kitöltött kérdőívet 500 kiküldött kérdőívből. A 383 vizsgálati személy közül a nemek eloszlását tekintve a válaszadók $80 \%$ nő, 20\% férfi. A résztvevők közül a legfiatalabb kérdőívet kitöltő pedagógus 23 éves, a legidősebb 69 éves, a vizsgálati minta átlagéletkora 41, 7 év.

\section{A vizsgálat eredményeinek bemutatása}

A kérdőív első részében egy 1-től 4 fokig terjedő Likert-skálán kellett a résztvevőknek vélekedni arról, hogy milyen mértékben értenek egyet a tanulás célját, a tanár szerepét, a diák szerepét, az osztálytermi folyamatokat értékelő kijelentések hagyományos, illetve alternatív értelmezésével. A skála értékei közül az 1 értéktől: „Egyáltalán nem értek egyet" vélekedéstől növekvő módon fokozatosan halad a 4 értékig: „Teljes mértékben egyet értek" vélekedésig.

A skála kérdéseire, illetve kategóriáira kapott átlagértékét az 3. táblázatban mutatjuk be.

\begin{tabular}{|c|c|c|}
\hline A vizsgálat eredményeinek összesítése & $\begin{array}{c}\text { Hagyományos } \\
\text { nézetek }\end{array}$ & Alternatív nézetek \\
A tanulás céljára vonatkozó nézetek. & 2,6 & 3,3 \\
A tanár szerepének értelmezésére vonatkozó nézetek. & 1,6 & 3,3 \\
A tanuló szerepének értelmezésére vonatkozó nézetek. & 2,4 & 2,8 \\
Az osztálytermi folyamatokra vonatkozó nézetek. & 2,9 & 3 \\
\hline Itemek összesítése & 2,6 & 3 \\
\hline
\end{tabular}

3. táblázat: A hagyományos és alternatív nézetek átlagértékeinek eloszlása

$\mathrm{Az}$ átlagértékek eloszlását tekintve elmondhatjuk, hogy összességében, illetve külön értelmezve a tanulás célját, a tanár szerepét, illetve a tanuló szerepét tekintve az alternatív szemlélet tükröződik a tanárok nézeteiben, ellentétben az osztálytermi folyamatokat tekintve a hagyományos szemlélet nagyobb mértékben jelenik meg, mint az alternatív szemlélet. A két szemlélet közötti különbség nem mondható számottevőnek, mutató értékű, azt igazolva, hogy amint a szakirodalomban is megjelenik: Halász (2014) tanulmányában ugyancsak a tanulási folyamatot megújító szemlélet implementálásának nehézségeiről ír.

A kapott értékek eloszlását szemléltetjük az 1. ábrán.

Az osztálytermi folyamatokat tekintve az osztályvezetési stílusok közül az intervencionalista és az interakcionalista stílus egyenlő arányban jelenik meg, mindkettő 3 átlag értéket kapott a maximum 4-ből. A kapott érték nincs összhangban a skála első felében felmért osztálytermi folyamatok hagyományos szemléletével, mivel a hagyományos szemlélet az interakcionalista osztályvezetési 
Az oktatás céljáról, a tanári szerepről, a diákszerepről...

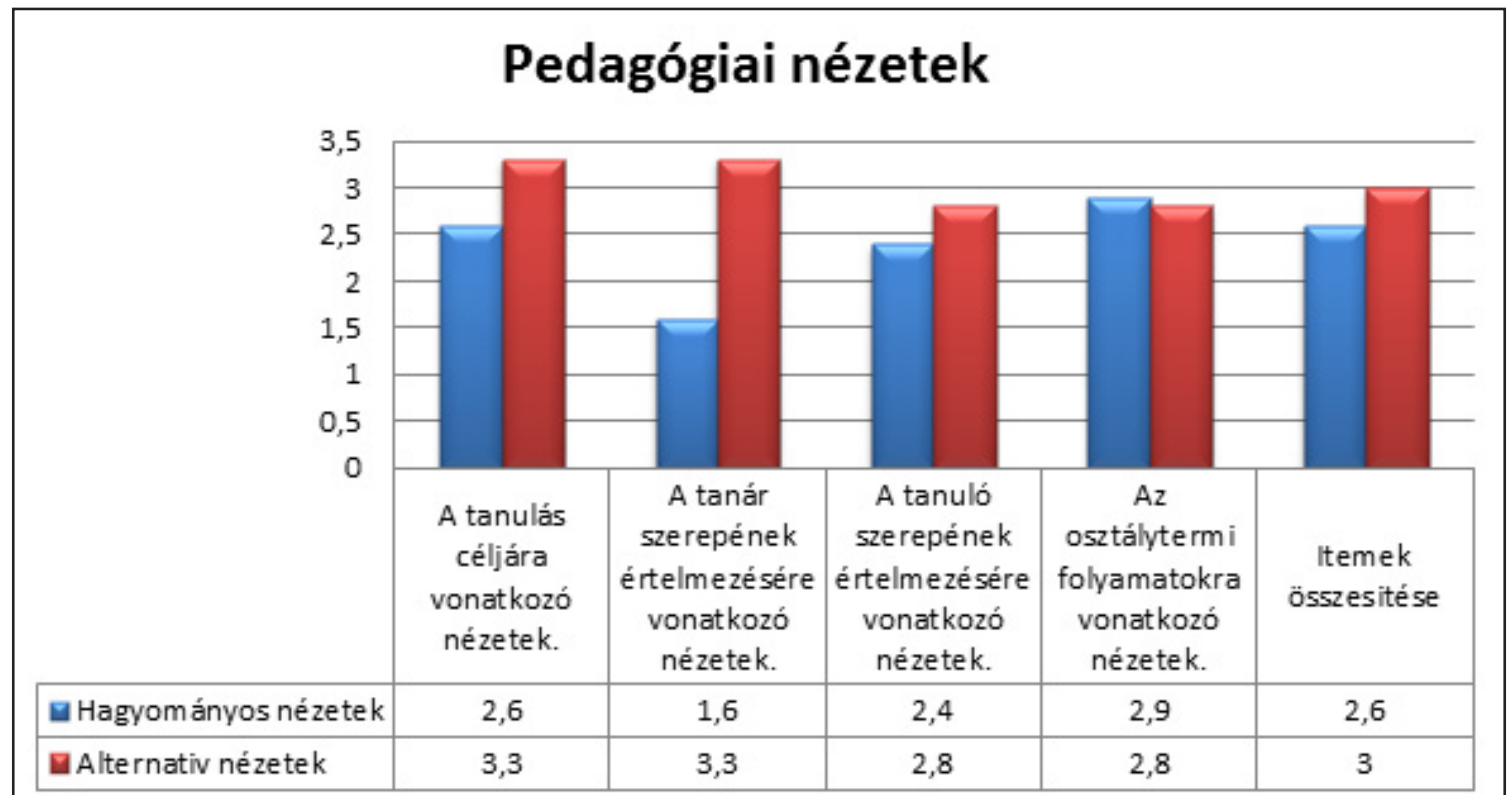

1. ábra: A hagyományos és alternatív nézetek átlagértékeinek eloszlása

stílust érvényesíti leginkább. Alacsonyabb natkozó átlagértékek eloszlását a 2. ábrán átlagértéket kapott a nem-intervencionalista összesítettük.

2,5 értéket. Az osztályvezetési stílusra vo-

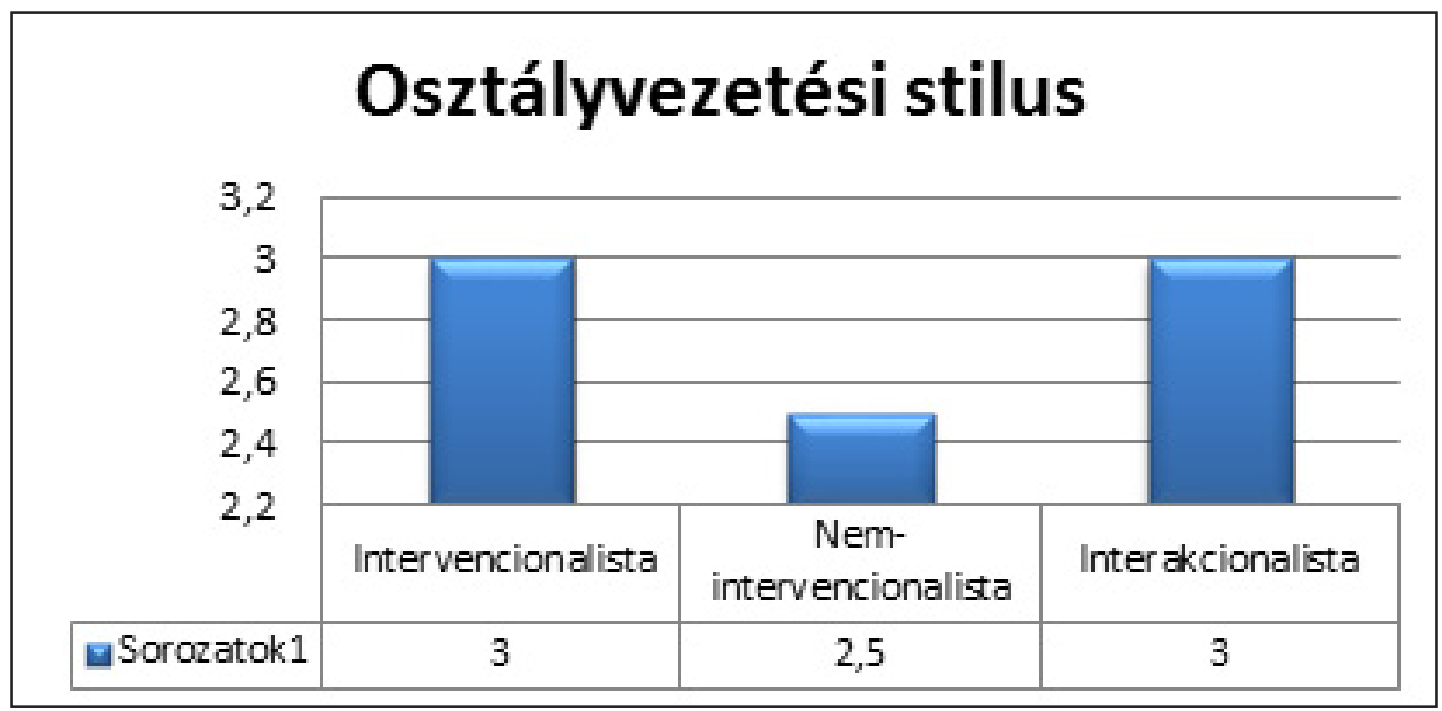

2. ábra: Az osztályvezetési stílus átlagértékeinek eloszlása

A kérdőív második felében arra kértük a

A válaszok eloszlásának arányát a 4. táblávizsgálatban résztvevő pedagógusokat, hogy hét javasolt metafora közül válasszanak ki egyet, melyhez a pedagógus leginkább hasonlítható.

\begin{tabular}{|c|c|c|c|c|c|c|c|}
\hline Minta & Állatorvos & Bíró & Bábművész & Showman & Karmester & Kereskedő & Állatidomár \\
\hline 308 válasz & $2,3 \%$ & $2,6 \%$ & $12,0 \%$ & $9,1 \%$ & $59,7 \%$ & $11,0 \%$ & $3,2 \%$ \\
\hline 75 hiányzó válasz & 7 & 8 & 37 & 28 & 184 & 34 & 10 \\
\hline
\end{tabular}

4. táblázat: A pedagógusok által választott metaforák átlagértékeinek eloszlása 
Kardos Melinda

A 383 válaszadó közül 308 értékelést kaptunk, 75 személy nem válaszolt erre a kérdésre.

A válaszadók részt $(59,7 \%)$ a „Karmesterhez" hasonlítják a pedagógus munkáját, ezt követi a „Bábművész” (12\%), illetve a „Kereskedő" (11\%). Értelmezésünk szerint a választott metaforák összefüggenek a skálán megjelenő értékekkel, mivel a „Karmester” szerep a pedagógust irányító szerepben tünteti fel, ami a hagyományos oktatási szemléletet tükrözi, ugyanakkor jelentős szerepet kap a zenekar, azaz a tanulók is, ami az alternatív szemlélet sajátossága. E szerint az értelmezés szerint, akárcsak a skála értékei szerint a pedagógusok nézeteiben mindkét szemlélet elemei megjelennek. A második legnagyobb értéket kapó „Bábművész” metafora a pedagógust aktív szerepben, ellenben a tanulót megfigyelö, azaz passzív szerepben tünteti fel, ami a hagyományos nézeteket és az intervenconalista oktatási stílust tükrözi. A harmadik leggyakoribb választott metafora a "Kereskedő" az adok-veszek folyamatot szem elött tartva ugyancsak a skála értékeiben megjelenő osztályvezetési stílust tükrözi, vagyis az interakcionalista stílust, melynek során a tanár és a diák is szerepet kap. A metaforák értékeinek eloszlását a 3. ábrán szemléltettük.

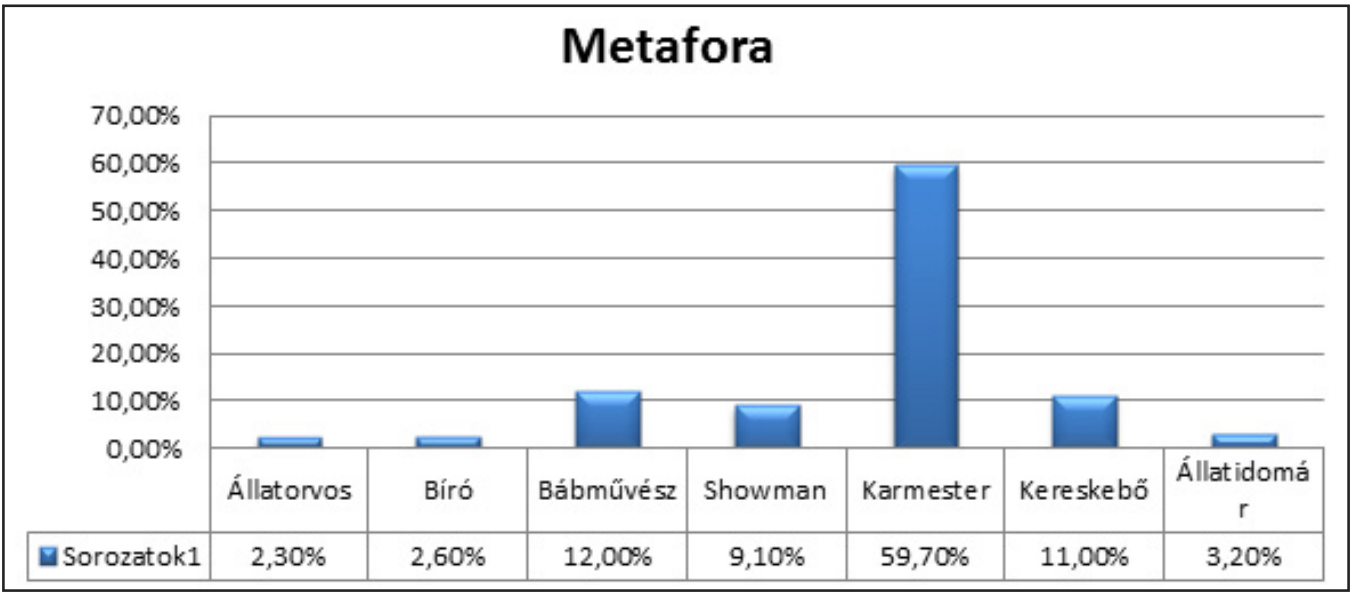

3. ábra: A pedagógusok által választott metaforák átlagértékeinek eloszlása

A mondat-befejezési technika alkalmazása során az oktatás céljára (M1.), a tanár szerepére (M2.), a tanuló szerepére ( M3.) és a tanár-diák kapcsolatra vonatkozóan kezdtünk el mondatokat, melyeknek a pedagógusok választottak befejezést két megadott lehetőség közül, me- lyek szerint az a. mondatbefejezés mindegyik mondat esetében a hagyományos szemléletet, ellenben a $b$. mondatbefejezés mindegyik mondat esetében az alternatív szemléletet tükrözte. A választott mondatbefejezések eloszlásának arányát a 4. ábrán szemléltetjük.

\section{Mondatbefejezés}

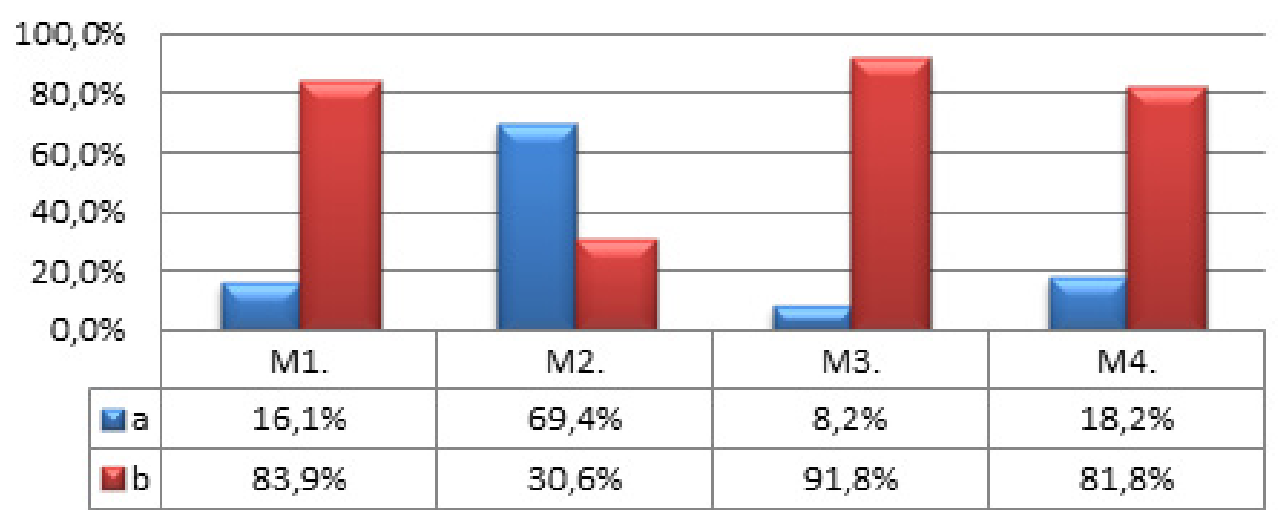

4. ábra: A pedagógusok által választott mondatbefejezések átlagértékeinek eloszlása 
Az oktatás céljáról, a tanári szerepről, a diákszerepről...

Amint azt az ábra is mutatja, a választott mondatbefejezések közül túlnyomórészt az alternatív szemlélet tükröződik a az oktatás céljára, a tanuló szerepére, illetve a tanár-diák kapcsolatra vonatkozó mondatok befejezésének választásában, kizárólag a tanár szerepére vonatkozó mondat választott befejezése tükrözi a hagyományos szemléletet.

\section{Következtetések}

A vizsgálat során összesített adatok részben igazolják felvetésünket, miszerint a tanárok nézetrendszere és az osztálytermi kommunikációs viselkedése között összefüggéseket figyelhetünk meg: a pedagógusok nézeteiben megjelenik az alternatív szemlélet, ellenben az osztálytermi folyamatok vezetésében leginkább a hagyományos szemléletet alátámasztó intervencionalista osztályvezetési stílus jelenik meg. Beigazolódott feltételezésünkben az a része melyben az alternatív szemlélet elemeinek jelenlétére tértünk ki a pedagógusok nézeteiben, a skála átlagértékei, a metaforaválasztás és a mondatbefejezések egyaránt rámutattak az alternatív nézetek jelenlétére, azonban az a rész hipotézisünkben, melyben az osztálytermi folyamatokra tértünk ki részben igazolódott be, mivel nem egyöntetűen az intervencionalista óravezetési stílus a jellemző a megkérdezett pedagógusok körében, ugyancsak megjelenik az intervencionalista stílus mellett az intekconaliata stílus is.

Értelmezésünk szerint a megkérdezett pedagógusok körében elkezdődött egy váltás a hagyományos szemléletről az alternatív szemlélet irányába, azonban ez a váltás az oktatási gyakorlatban nehézkesen épül be, a vélekedések szintjén is.

Továbbfejlesztési javaslatként érdemes lenne a mindennapi oktatási gyakorlat megvalósulását alaposabban megvizsgálni, érdemes lenne a megkérdezett pedagógusok nézeteit és osztálytermi megnyilvánulásait az óráikról rögzített videofelvételek elemzésével mélyfúrásszerűen vizsgálni.

\section{Felhasznált irodalom}

Bábosik István (2006): Nevelés a tudásalapú társadalomban. In: Kelemen Elemér és Falus Iván (szerk.) Tanulmányok a neveléstudományok köréből. Műszaki Kiadó,Budapest, 11-24.

Eveyik, A. E., Kurt, G., Made, E. (2009): Exploring the relationship between teacher beliefs and styles on classroom management in relation to actual teaching practices: a case study. World Conference on Educational Sciences, Nicosia, North Cyprus, New Trends and Issues in Educational Sciences, 1. 1. szám, 612-617.

Halász Gábor (2014): Eredményes tanulás, kurrikulum, oktatáspolitika. In: Benedek András és Golnhofer Erzsébet (szerk.) Tanulmányok a neveléstudomány köréböl - 2013: Tanulás és környezete. MTA Pedagógiai Tudományos Bizottság, Budapest, 79-104.

Knoblauch, D. \& Chase, M., A. (2015): Rural, suburban, and urban schools: The impact of school setting on the efficacy beliefs and attributions of student teachers. Teaching and Teacher Education, 45, 104-114.

Langerné Buchwald Judit (2010): A reformpedagógiai iskolakoncepciók és az alternativi iskolák elterjedésének korlátai és lehetöségei a közoktatásban, Pannon Egyetem, Neveléstudományok Doktori Iskola, Doktori PhD értekezés. URL: http://konyvtar.uni-pannon.hu/doktori/ 2010/Langerne_Buchwald_Judit_dissertation.pdf

Pakarinen, E., Aunola, K., Kiuru, N., Lerkkanen, M., K., Poikkeus, A., M., Siekkinen, M., Nurmi, J., E. (2014): The cross-lagged associations between classroom interactions and children's achievement behaviors. Contemporary Educational Psychology, 39, 248-261.

Petek, E. (2013): Teacher's Beliefs about Classroom Interaction and their Actual Practices: A Qualitative Case Study of a Native and a Non-native English Teacher's In-class Applications. Procedia - Social and Behavioral Sciences, 70, 1195-1199.

Rahimi, M. \& Asadolallahi, F. (2012): On the relationship between Iranian EFL teachers' classroom management orientations and teaching style. Procedia Social and Behavioral Sciences, 31, 49-55.

Riensties, B., Brower, N., Lygo-Baker, S. (2013): The effects of online professional development on higher education teachers' beliefs and intentions towards learning facilitation and technology. Teaching and Teacher Education, 29, 122-131. 
Ritter, J. T., Hancock, D. R. (2007): Exploring the relationship between certification sources, experience levels, and classroom management orientations of classroom teachers. Teaching and Teacher Education, 23, 1206-1216.

Sántha Kálmán (2009): Bevezetés a kvalitatív kutatások módszertanába. Eötvös József Kiadó, Budapest.
Trif Letitia (2012): Didactica din perspectiva centrarii pe elev, Academia de vara,Universit atea,1Decembrie1918”,AlbaIulia.

URL: http://portal.didacticieni.ro/documents/ 41587/47997/Trif+L_Didactica+centrarii+ pe+elev.pdf

\section{Teachers' beliefs on the purpose of learning, teachers' and students' role as well as on the} classroom interaction

Classroom interaction and the teachers' beliefs are important in the process of effective learning process. In the first part of this paper reports the author provides exploratory findings of the studies focusing on the beliefs and the classroom interactions. The second part attempts to unveil the relationship between teachers' beliefs and classroom interaction and their actual practices. The findings of the study indicate contradiction between teachers' beliefs and their actual practices which will be discussed in detail in an other study.

Keywords: learning process, teachers' beliefs, classroom interaction, teacher's role, student's role

Kardos Melinda (2017): Az oktatás céljáról, a tanári szerepről, diákszerepről és osztálytermi interakcióról vallott pedagógusi nézetek. Gyermeknevelés, 5. 3. sz., 18-28. 